\title{
STRATEGI COPING PADA MANTAN PENGANUT ALIRAN SESAT
}

\author{
Khairunnisa Putri \\ Sri Kushartati \\ Fakultas Psikologi \\ Universitas Ahmad Dahlan Yogyakarta \\ Email: khairunnisa2017@yahoo.com
}

\begin{abstract}
This study aims to find out about the coping strategies on the former follower of a cult and the factors that influence them. Two respondents participated in this study. The method in this study uses a qualitative method with a phenomenological approach. The results of this study indicate that the two respondents perform coping strategy to reduce pressure felt. They use emotional focused coping in the form of distancing, escape avoidance, self-control, accepting responsibility, positive reappraisal, and denial. Planfull problem solving is used as a form of problem-focused coping. Known to both the subject of coping processes that vary in shape using coping strategies influenced by physical health factors, problem solving skills, and social skills.

Keywords : Coping Strategy, former cult follower, emotional focused coping, problem focused coping

Penelitian ini bertujuan untuk mengeksplorasi strategi coping pada mantan penganut aliran sesat dan faktor yang mempengaruhinya. Dua responden berpartisipasi dalam penelitian ini. Penelitian ini menggunakan metode kuantitatif dengan pendekatan fenomenologi. Hasil dari penelitian ini menunjukkan bahwa kedua responden menggunakan strategi coping untuk mengurangi tekanan yang mereka rasakan. Mereka menggunakan emotional focused coping yang berbentuk distancing, escape avoidance, self-control, accepting responsibility, positive reappraisal, dan denial. Disamping itu, planfull problem solving digunakan sebagai bentuk problem-focused coping. Proses coping pada kedua subjek bervariasi dalam bentuknya dipengaruhi oleh faktor kesehatan fisik, ketrampilan pemecahan masalah dan ketrampilan sosial.
\end{abstract}

Kata kunci: strategi coping, mantan penganut aliran sesat, emotional focused coping, problem focused coping

\section{Pendahuluan}

Undang-Undang Dasar pasal 28 ayat (2) menyatakan "setiap orang bebas memeluk agama dan beribadah menurut agamanya, memiliki pendidikan dan pengajaran, memilih pekerjaan, memilih kewarganegaraan, memilih tempat tinggal di wilayah Negara dan meninggalkannya serta berhak kembali". Berdasarkan UUD tersebut, Pemerintah secara resmi mengakui enam agama, yaitu Islam, Katolik, Protestan, Budha, Hindu, dan Konghucu. Secara umum Pemerintah menghargai kebebasan menjalankan ibadah agama, namun ada pembatasan yang terus berlangsung dari pemerintah khususnya pada agama yang tidak diakui dan sekte agama yang dianggap menyimpang. Kata menyimpang juga dapat diartikan dengan sebuah kegiatan agama yang sesat atau aliran sesat. 
Menurut Zamihan dan Al-Ghari (2008), aliran sesat adalah suatu ajaran, pemahaman atau amalan yang didakwa sebagai ajaran Islam tetapi bukan dari ajaran Islam bahkan bertentangan dengan ajaran Islam. Pengurus Besar Nahdatul Ulama (PBNU) mencatat, sejak tahun 2001 hingga 2008 sedikitnya ada sekitar 250 paham atau aliran yang menyimpang berkembang di Indonesia, mulai dari aliran kerajaan Lia Eden, pemimpin agama "Salamullah" yang mengaku dirinya sebagai perwakilan Jibril, pengikut "Al-Qiyadah" yang mengimani Ahmad Musaddeq sebagai Rasulnya dan beberapa aliran sesat lainnya. Ciri-ciri dari kesesatan atau aliran sesat yang berkembang di Indonesia, dikemukakan oleh Majelis Ulama Indonesia yang mengeluarkan maklumat tentang 10 ciri aliran sesat (Almarwadi, 2012), yaitu:

1. Mengingkari rukun iman dan rukun islam.

2. Meyakini dan atau mengikuti akidah yang tidak sesuai dalil syar' $i$.

3. Meyakini turunnya wahyu setelah Al-Quran.

4. Mengingkari otentisitas atau kebenaran isi Al-Quran.

5. Melakukan penafsiran Al-Quran yang tidak berdasarkan kaidah-kaidah tafsir.

6. Mengingkari kedudukan hadits Nabi SAW sebagai sumber ajaran islam.

7. Menghina, melecehkan dan atau merendahkan para Nabi dan Rasul.

8. Mengingkari Nabi Muhammad SAW sebagai Nabi dan Rasul terakhir.

9. Mengubah, menambah dan atau mengurangi pokok-pokok ibadah yang telah ditetapkan oleh syari'ah, seperti haji tidak ke Baitullah dan shalat fardhu tidak lima waktu.

10. Mengkafirkan sesama muslim tanpa dalil syar'i, seperti mengkafirkan seorang muslim hanya karena bukan kelompoknya.

Zamihan dan Al-Ghari (2008) mengatakan bahwa seseorang yang terlibat dengan aliran sesat menjadikan hidupnya tidak seimbang antara tuntutan dunia dan akhirat. Hal tersebut menjadikan dirinya berada di antara dilema dalam mencari pegangan dan amalan hidup yang sebenarnya. Selain itu, dia juga tidak merasakan nikmat hidup beragama dengan penuh ketenangan.

Melalui penelitian awal, telah diamati dua orang subjek yang keluar dari sebuah aliran sesat. Ditemukan bahwa kedua subjek tersebut selama mengikuti aliran yang dianut, sering mendapat tekanan-tekanan, seperti tidak diperbolehkan bertemu dengan teman-teman di kampusnya, wajib melaporkan segala bentuk aktivitas selama 24 jam, dituntut untuk bertemu setiap hari, dan penarikan uang secara paksaan. Karena tekanan yang dialami, kedua subjek tersebut memutuskan untuk keluar dari aliran sesat. Setelah keluar dari aliran tersebut subjek masih mengalami tekanan berupa didatangi oleh anggota dari aliran itu.

Secara umum, ketika seseorang mengalami sebuah tekanan, mereka akan melakukan berbagai strategi coping dalam menghadapi penyelesaian masalahnya. Menurut Lazarus dan Folkman (Lazarus, 1991), coping adalah usaha perubahan kognitif dan perilaku secara konstan untuk mengelola tuntutan eksternal dan/atau internal tertentu yang dinilai sebagai membebani atau melampaui sumber daya seseorang. Dengan kata lain, definisi ini mencakup berbagai target koping baik internal (seperti reaksi emosional) atau eksternal (seperti situasional). Perrewe dan Ganster (2006) mendefinisikan coping sebagai berbagai respon terhadap tekanan peristiwa kehidupan dengan cara mencegah, menghindari atau mengontrol distres emosional. Dapat disimpulkan bahwa koping merupakan proses individu berusaha untuk menangani dan menguasai situasi yang menekan, yang dinilai sebagai membebani atau melampaui sumber daya seseorang dengan cara melakukan perubahan kognitif maupun perilaku guna memperoleh rasa aman.

Menurut Lazarus (1986), ada dua jenis strategi coping, yaitu emotional focused coping dan problem focused coping. 
a. Emotional focused coping adalah penanganan stres dengan mengendalikan respon emosi yang diakibatkan oleh stressor. Emotional focused coping lebih menekankan pada usaha untuk menurunkan emosi negatif yang dirasakan ketika menghadapi masalah atau tekanan. Adapun aspek-aspeknya, meliputi :

1) Seeking social emotional support, yaitu mencoba untuk memperoleh dukungan secara emosional maupun sosial dari orang lain.

2) Distancing, yaitu mengeluarkan upaya kognitif untuk melepaskan diri dari masalah atau membuat sebuah harapan positif.

3) Escape avoidance, yaitu mengkhayal mengenai situasi atau melakukan tindakan atau menghindar dari situasi yang tidak menyenangkan. Individu melakukan fantasi andaikan permasalahannya pergi dan mencoba untuk tidak memikirkan mengenai masalah dengan tidur atau menggunakan alkohol yang berlebih.

4) Self control, yaitu mencoba untuk mengatur perasaan diri sendiri atau tindakan dalam hubungannya untuk menyelesaikan masalah.

5) Accepting responsibility, yaitu menerima untuk menjalankan masalah yang dihadapinya sementara mencoba untuk memikirkan jalan keluarnya.

6) Positive reappraisal, yaitu mencoba untuk membuat suatu arti positif dari situasi dalam masa perkembangan kepribadian, kadang-kadang dengan sifat yang religius.

b. Problem focused coping adalah penanganan stres dengan cara mengurangi, atau memecahkan masalah yang menjadi sumber stres. Problem- focused coping biasanya langsung mengambil tindakan untuk memecahkan masalah atau mencari informasi yang berguna untuk membantu pemecahan masalah. Adapun aspek-aspeknya, meliputi :

1) Seeking informational support, yaitu mencoba memperoleh informasi dari orang lain, seperti dokter, psikolog, atau guru.

2) Confrontive coping, yaitu menyelesaikan masalah secara konkret.

3) Planfull problem solving, yaitu menganalisis setiap situasi yang menimbulkan masalah serta berusaha mencari solusi secara langsung terhadap masalah yang dihadapi.

Menurut Lazarus dan Folkman (Sarafino, 2008) terdapat beberapa faktor yang mempengaruhi strategi coping, yaitu :

\section{a. Kesehatan fisik}

Kesehatan merupakan hal yang penting, karena selama dalam usaha mengatasi stres individu dituntut untuk mengerahkan tenaga yang cukup besar.

b. Keterampilan memecahkan masalah

Keterampilan ini meliputi kemampuan untuk mencari informasi, menganalisa situasi, mengidentifikasi masalah dengan tujuan untuk menghasilkan alternatif tindakan, kemudian mempertimbangkan alternatif tersebut sehubungan dengan hasil yang ingin dicapai, dan pada akhirnya melaksanakan rencana dengan melakukan suatu tindakan yang tepat.

c. Keyakinan atau pandangan positif

Keyakinan menjadi sumber daya psikologis yang sangat penting, seperti keyakinan akan nasib (eksternal locus of control) yang mengerahkan individu pada penilaian ketidakberdayaan (helplessness) yang akan menurunkan kemampuan strategi coping

d. Keterampilan sosial

Keterampilan ini meliputi kemampuan untuk berkomunikasi dan bertingkah laku dengan cara-cara yang sesuai dengan nilai-nilai sosial yang berlaku di masyarakat. 


\section{e. Dukungan sosial}

Dukungan ini meliputi dukungan pemenuhan kebutuhan informasi dan emosional pada diri individu yang diberikan oleh orang tua, anggota keluarga lain, saudara, teman, dan lingkungan masyarakat sekitarnya.

\section{f. Materi}

Dukungan ini meliputi sumber daya berupa uang, barang-barang atau layanan yang biasanya dapat dibeli.

Menurut Qurays (2013), sesat atau kesesatan yang berarti dhalal (dalam bahasa arab) yaitu setiap bentuk penyimpangan dari jalan yang dituju (benar) dan setiap yang berjalan bukan pada jalan yang benar. Adapun tujuan munculnya aliran sesat adalah untuk menghancurkan akidah umat Islam Indonesia. Adapun aliran sesat yang sering muncul di Indonesia, seperti; Lia Eden, Ahmadiyah, Isa Bugis, NII, dan LDII.

Salah satu aliran sesat yang akan dibahas dalam penelitian ini adalah NII (Negara Islam Indonesia). Menurut Hadhi, dkk. (2005), beberapa tahun belakangan, muncul suatu pembahasan di berbagai kalangan tentang kembali bangkitnya pergerakan NII yang konon menyimpang jauh dari ajaran Al-quran dan As-sunnah. NII dikatakan menyimpang dari Al-qur'an dan As-sunnah karena memiliki ciri-ciri yang dijelaskan sebagai berikut :

a. Dalam "mendakwahi" calonnya, mata sang calon ditutup rapat, dan baru akan dibuka ketika mereka sampai ke tempat tujuan.

b. Para calon yang akan mereka "dakwahi" rata-rata memiliki ilmu keagamaan yang relatif rendah, bahkan dapat dibilang tidak memiliki ilmu agama. Sehingga, para calon dengan mudah "dijejali" pemahaman yang menurut mereka adalah pemahaman tentang Dinul Islam (agama islam).

c. Calon utama adalah orang-orang yang memiliki harta yang berlebihan, atau yang orang tuanya berharta lebih, anak-anak orang kaya yang jauh dari keagamaan, sehingga yang terjadi adalah penyedotan uang para calon dengan dalih Islam.

d. Pola dakwah yang relatif singkat, hanya kurang lebih tiga kali pertemuan. Setelah itu, sang calon dimasukkan ke dalam keanggotaan mereka. Sehingga, yang terkesan adalah pemaksaan ideologi, bukan lagi keikhlasan. Selama hari terakhir pendakwahan, sang calon dipaksa dengan "dijejali" ayat-ayat yang mereka terjemahkan seenaknya hingga sang calon mengatakan siap dibai'at (sumpah).

e. Ketika calon akan dibai'at (sumpah), dia harus menyerahkan uang yang mereka namakan dengan uang penyucian jiwa. Besar uang yang harus diberikan adalah Rp 250.000 ke atas. Jika sang calon tidak mampu saat itu, maka infaq itu menjadi hutang sang calon yang wajib dibayar.

f. Tidak mewajibkan menutup aurat bagi anggota wanitanya dengan alasan kahfi.

g. Tidak mewajibkan shalat lima waktu bagi para anggotanya dengan alasan belum futuh (menang).

h. Sholat lima waktu mereka ibaratkan dengan doa dan dakwah. Sehingga, jika mereka sedang berdakwah, maka saat itulah mereka anggap sedang mendirikan shalat.

i. Shalat Jum'at diibaratkan dengan rapat atau syuro. Sehingga, pada saat mereka rapat, maka saat itu pula mereka menganggap sedang mendirikan shalat Jum'at.

j. Infaq yang dipaksakan setiap bulan, sehingga menjadi hutang yang wajib dibayar.

k. Adanya qiradh (uang yang dikeluarkan untuk dijadikan modal usaha) yang diwajibkan walaupun anggotanya tidak memiliki uang, bila perlu berhutang kepada kelompoknya. Apabila pembagian hasil dari qiradh yang mereka janjikan tidak kunjung datang, dan jika diminta tentang pembagian hasil bagi itu, mereka menjawabnya dengan ayat Al- qur'an sedemikian rupa sehingga upaya meminta bagi hasil itu menjadi hilang. 
1. Zakat yang tidak sesuai dengan syari'at Islam. Takaran yang terlalu melebihi dari yang semestinya. Mereka mensejajarkan sang calon dengan sahabat Abu Bakar dengan menafikan syari'at yang sesungguhnya.

m. Tidak adanya mustahik di kalangan mereka, sehingga bagi mereka yang tak mampu makan sekalipun, wajib membayar zakat yang besarnya sebanding dengan dana untuk makan sebulan.

n. Belum berlakunya syari'at Islam di kalangan mereka sehingga perbuatan apapun tidak mendapatkan hukuman.

o. Mengkafirkan orang yang berada di luar kelompoknya, bahkan menganggap halal berzina dengan orang di luar kelompoknya.

p. Manghalalkan mencuri atau mengambil barang milik orang lain.

q. Menghalalkan segala cara demi mencapai tujuan, seperti menipu atau berbohong meskipun kepada orang tua sendiri.

Sarafino (2008) menyatakan bahwa dalam menghadapi tekanan ada dua jenis strategi coping yang digunakan, yaitu emotional focused coping dan problem focused coping. Emotional focused coping adalah bentuk coping yang ditujukan untuk mengendalikan respons emosional terhadap situasi stres, sedangkan problem focused coping ditujukan agar mengurangi tuntutan situasi stressful atau mengeluarkan sumber-sumber untuk mengurangi masalah.

Tujuan dari penelitian ini adalah ingin mengetahui coping apa saja yang digunakan dan bagaimana proses coping itu digunakan, serta faktor-faktor apa saja yang mempengaruhi coping.

\section{METODE PENELITIAN}

Peneliti ini menggunakan penelitian kualitatif fenomenologi, karena peneliti dapat mengungkapkan permasalahan yang akan diteliti secara lebih mendalam. Hubungan yang baik dengan subjek penelitian juga dapat sangat menentukan hasil penelitian.

Pemilihan subjek dalam penelitian ini menggunakan satu jenis sampling, yaitu menggunakan pemilihan subjek berdasarkan tujuan (purposive sampling), yaitu peneliti memilih subjek yang mempunyai pengetahuan dan informasi tentang fenomena yang sedang diteliti.

Peneliti menggunakan metode wawancara semi terstuktur dengan harapan dapat menggali permasalahan dengan baik dan mendalam. Tujuan dari wawancara semi terstruktur menurut Esterberg (Sugiyono, 2011) adalah untuk menemukan permasalahan secara lebih terbuka, dimana pihak yang menjadi responden dalam wawancara juga diminta pendapat dan ide-idenya. Selain menggunakan wawancara, peneliti juga menggunakan alat pengumpul data yang lain yaitu observasi. Observasi yang digunakan adalah observasi non partisipan, yaitu peneliti tidak ikut terlibat langsung dengan subjek penelitian, hanya mengamati semua aktivitas yang dilakukan oleh subjek. Metode pencatatan yang digunakan adalah anecdotal record, yaitu mencatat perilaku yang muncul sesuai aspek yang ingin dilihat dan mencatat hal-hal lain yang dianggap penting.

Tahap awal penelitian, peneliti membuat guide wawancara dengan bentuk wawancara semi terstruktur untuk memudahkan peneliti dalam memberikan pertanyaan yang sesuai dan tidak melenceng dari apa yang menjadi fokus dari tujuan penelitian. Peneliti juga dapat mengembangkan pertanyaan sesuai dengan kebutuhan informasi yang ingin didapatkan sehingga informasi yang didapatkan menjadi lebih banyak dan mendalam.

Tahap selanjutnya adalah pelaksanaan penelitian. Peneliti membuat kesepakatan dengan responden mengenai waktu pelaksanaan dan tempat yang akan digunakan untuk wawancara. Ketika wawancara berlangsung peneliti juga melakukan observasi non partisipan dengan melihat kemungkinan-kemungkinan yang dimunculkan subjek selama proses wawancara 
berlangsung yang berkaitan dengan tujuan penelitian. Selain mencatat, peneliti juga merekam pembicaraan dengan responden guna menghindari adanya informasi yang tercecer karena lupa.

Pendekatan analisis data yang digunakan dalam penelitian ini adalah meaning interpretation atau biasa disebut dengan analisis isi (content analysis). Menurut Moleong (2012), analisis isi adalah analisis data yang terdiri dari meaning unit (pokok pikiran), makna deskriptif (menarasikan kembali keseluruhan tema dengan bahasa sendiri), dan makna interpretatif (menginterpretasikan menurut sudut pandang teoritik).

Dalam penelitian ini, peneliti menggunakan kredibilitas dan dependabilitas sebagai keterpercayaan penelitian. Kredibilitas penelitian kualitatif, dapat diupayakan melalui triangulasi data. Data triangulasi yang digunakan adalah triangulasi metode, yaitu untuk menguji kredibilitas data yang dilakukan dengan metode yang berbeda, seperti data diperoleh dengan wawancara, lalu dicek dengan teknik observasi. Sedangkan dependabilitas penelitian kualitatif, dapat diupayakan melalui "member check". "member check" merupakan pengembalian transkrip (hasil wawancara) atau hasil penelitian kepada subjek dengan tujuan mendapatkan rekonfirmasi dari mereka bahwa hasil wawancara telah benar atau sesuai demikian adanya.

\section{HASIL DAN PEMBAHASAN}

\section{A. Strategi coping yang digunakan Mantan Penganut Aliran sesat}

Berdasarkan teori yang telah dikemukakan sebelumnya, peneliti menemukan jenis strategi coping yang digunakan oleh kedua subjek penelitian, yaitu emotional focused coping dan problem-focused coping dengan perbedaan proses coping pada masing-masing subjek. Menurut Nurhayati (2006), kemampuan setiap individu dalam memilih strategi coping dan menggunakannya untuk mengurangi tekanan adalah berbeda. Perbedaan juga terdapat dalam hal pemahaman mengenai bagaimana dan kapan harus memakai strategi coping yang diperlukan.

Berdasarkan hasil penelitian, ditemukan bahwa subjek Bondan dan Bunga sama-sama lebih menggunakan emotional focused coping dibandingkan menggunakan problem focused coping dalam menghadapi setiap masalah. Menurut Greenglass dan Noguchi (Sarafino, 2006), pada umumnya studi perbedaan gender menemukan bahwa pria lebih menggunakan problem focused coping dan wanita lebih menggunakan emotion focused coping dalam penyelesaian masalahnya. Namun, ketika pria dan wanita memiliki pekerjaan-pekerjaan dan pendidikan yang serupa, maka tidak ada perbedaan gender yang ditemukan. Hal tersebut sesuai dengan kondisi kedua subjek dimana keduanya memiliki pekerjaan dan pendidikan yang serupa, maka kedua subjek diduga memiliki kecenderungan menilai kemampuannya sendiri untuk menyelesaikan masalah. Dalam penelitian ini, peneliti juga menduga penilaian subjek terhadap kemampuannya dalam menyelesaikan masalah lebih berpengaruh daripada faktor gender untuk pemilihan strategi coping. Hal tersebut dikenal dengan penilaian kognitif (cognitive appraisal). Lazarus (Sarafino, 1998) mengemukakan penilaian kognitif (cognitive appraisal) merupakan proses mental yang dinilai oleh individu melalui dua faktor, yaitu : 1) Tuntutan yang mengancam pada kesejahteraan individu, 2) Penilaian sumber daya (kemampuan) yang tersedia untuk memenuhi tuntutan tersebut.

Secara umum, penilaian kognitif dibagi menjadi dua tahap, yaitu penilaian primer dan penilaian sekunder. Lazarus (1991) mengatakan bahwa ketika individu berhadapan dengan lingkungan yang baru atau perubahan lingkungan (situasi yang penuh tekanan), maka akan melakukan penilaian primer (primary appraisal) untuk menentukan arti dari kejadian tersebut. Kejadian tersebut dapat diartikan sebagai hal yang positif, netral, atau negatif. Setelah penilaian primer terhadap hal-hal yang mempunyai potensi terjadinya tekanan, maka penilaian sekunder (secondary appraisal) akan muncul. Penilaian sekunder adalah pengukuran terhadap 
kemampuan individu dalam mengatasi tekanan yang ada. Setelah memberikan penilaian primer dan sekunder, individu akan melakukan penilaian ulang (re-appraisal) yang akhirnya mengarah pada pemilihan strategi coping untuk penyelesaian masalah sesuai dengan situasi yang dihadapinya.

Hasil penelitian ini menemukan pemilihan bentuk strategi coping yang dilakukan oleh subjek Bondan dan Bunga. Peneliti akan memaparkan aspek emotional focused coping terlebih dahulu pada bentuk distancing yang digunakan subjek Bondan, yaitu ditunjukkan dengan pemikiran subjek yang menganggap NII telah menyimpang, kemudian subjek berpikir untuk melanggar aturan dengan mencari tahu tentang NII di internet, setelah yakin bahwa NII telah menyimpang subjek berpikir untuk keluar dari NII dengan cara memanfaatkan liburan kampus untuk pulang kampung dan menemukan keyakinan yang baru. Selain itu, subjek memilih untuk diam saja ketika diajak dan dibujuk untuk kembali ke NII lagi, subjek juga berpikir untuk mengikuti organisasi pada jurusan di kampusnya agar tidak bertemu dengan anggota NII lagi, hal ini sesuai dengan pendapat Lazarus (1999) bahwa dalam melakukan coping terhadap tekanan yang sangat mengancam, individu akan melakukan coping sesuai dengan pengalaman, keadaan, dan waktu saat ia melakukan coping tersebut.

Sementara pada subjek Bunga ditunjukkan ketika subjek merasakan dirinya selama di NII bukan menjadi individu yang baik melainkan menjadi penipu dengan berlandaskan Al-Quran. Oleh karena itu, subjek berpikir untuk keluar dari NII dan yakin dapat mengamalkan Al-Quran walaupun tidak berada di NII.

Bentuk escape avoidance digunakan oleh kedua subjek penelitian. Pada subjek Bondan ditunjukkan dari perilaku subjek yang memberikan alasan setiap kali diajak kembali ke NII, seperti alasan kuliah dan keperluan lain. Selain itu, ketika subjek dicurigai oleh teman-temannya di kampus perihal NII, subjek meresponnya dengan bergurau. Kemudian subjek berusaha agar tidak mengenang NII dengan bermain billiard dan "nongkrong" bersama teman-temannya, bahkan subjek menghilangkan beban pikirannya dengan mabuk dan merokok. Hal tersebut sesuai dengan penjelasan Lazarus (1999) bahwa individu dapat mengatur respon emosinya dengan beberapa cara, antara lain adalah dengan mencari dukungan emosi dari sahabat atau keluarga, melakukan aktivitas yang disukai, seperti olahraga atau nonton film untuk mengalihkan perhatian dari masalah, bahkan tak jarang dengan penggunaan alkohol atau obatobatan. Sementara pada subjek Bunga ditunjukkan dengan perilaku subjek yang menyibukkan diri dengan aktivitas kuliah dan berkumpul bersama teman-temannya setiap pulang kuliah agar tidak mengenang NII.

Bentuk self control digunakan juga pada kedua subjek penelitian. Pada subjek Bunga terlihat dari subjek mempertimbangkan ketika keluar dari NII dengan merasakan banyak kejanggalan, salah satunya NII menipu dengan menggunakan pedoman Al-Quran sehingga membuat subjek tidak yakin lagi, subjek juga mempertimbangkan untuk tidak menceritakan kepada siapapun perihal masuk di NII karena tidak mau dituduh menipu, ada kemungkinan subjek merasa bersalah terhadap orang-orang yang pernah ditipunya sehingga subjek tidak mau bercerita pada siapapun. Hal ini sesuai dengan pendapat Lewis dan Havilan (Saputra, 2011) bahwa rasa bersalah adalah emosi penyesalan yang dihasilkan ketika seseorang menilai perilaku mereka sendiri sebagai kegagalan. Jadi, rasa bersalah ada hubungannya dengan rasa malu dimana individu mengambilnya sesuai kebutuhan untuk memperbaiki kegagalan. Seperti yang dipaparkan oleh Pennebaker (Wade dan Tavris, 2007) bahwa perasaan malu dan tertekan dapat muncul karena individu menyimpan rahasia yang menyakitkan. Selain itu, subjek kembali bebas dan menjadi diri sendiri setelah keluar dari NII tanpa ada batasan lagi terutama untuk bergaul dengan teman-temannya. Sementara pada subjek Bondan hampir sama dengan yang dilakukan 
subjek Bunga yaitu ditunjukkan dengan kembali bebas melakukan aktivitas tanpa ada batasan dari NII, seperti kuliah dan berinteraksi bersama teman-temannya.

Sementara itu, bentuk accepting responsibility dari aspek emotion focused coping hanya ditunjukkan oleh subjek Bunga, dimana saat itu subjek merasa tertekan dijauhi oleh temanteman kuliahnya, karena salah satu dari temannya yang pernah bergabung di NII menyebarkan berita bahwa subjek adalah anggota NII, subjek mengambil sikap dengan menerima tekanan tersebut dan memilih keluar dari NII.

Adapun bentuk positive reappraisal dari aspek emotion focused coping ditunjukkan oleh kedua subjek penelitian. Subjek Bondan lebih religius setelah keluar dari NII seperti mengerjakan sholat, subjek juga lebih tertuntun melakukan aktivitas ibadah dan hal positif. Selain itu, subjek membandingkan apa yang seharusnya diyakini sehingga berhati-hati dalam melakukan tindakan apapun agar tidak terjerumus di NII lagi. Dalam hal ini subjek telah membuktikan aktualisasi dirinya setelah mengalami tekanan-tekanan di NII, seperti yang dijelaskan oleh Maslow (Alwisol, 2004) bahwa aktualisasi diri merupakan kebutuhan karena ingin berkembang, ingin berubah, ingin mengalami transformasi menjadi lebih bermakna atau being need. Sementara pada subjek Bunga terlihat dari subjek menjadi lebih dekat dan terbuka menceritakan apapun dengan orang tuanya setelah keluar dari NII, seperti yang diketahui semenjak subjek berada di NII subjek selalu disibukkan dengan aktivitas NII yang mengakibatkan subjek tertutup dan jarang bertemu dengan orang tuanya di rumah. Selain itu, kesuksesan juga menjadi harapan subjek setelah keluar dari NII dengan mengambil sisi positif dan membuang sisi negatif dari NII, salah satu sisi positif yang dapat diambil oleh subjek adalah selalu berpikir positif dalam hal apapun jika menghadapi suatu masalah. Menurut Ubaedy (Kuntjojo, 2009), berpikir positif merupakan usaha mengisi pikiran dengan berbagai hal yang positif atau muatan yang positif. Adapun yang dimaksud dengan muatan positif untuk pikiran yaitu; benar (tidak melanggar nilai-nilai kebenaran), baik ( untuk diri sendiri, orang lain, dan lingkungan), dan bermanfaat (menghasilkan sesuatu yang berguna).

Aspek problem focused coping bentuk planfull problem solving hanya terdapat pada subjek Bunga, dimana subjek menjadi jauh dari teman dan orang tuanya, ditambah dengan NII selalu meminta uang sehingga subjek tidak bisa "jajan" dan makan, akhirnya subjek berbohong bahwa tidak memiliki uang lagi agar tidak "dimintai" uang oleh NII. Oleh karena itu, subjek memilih untuk keluar dari NII dengan cara mengurangi komunikasi pada anggota NII. Dengan mengurangi komunikasi, subjek tidak dicari lagi oleh NII dan subjek telah dianggap meninggalkan NII, karena bagi NII komunikasi adalah salah satu hal yang paling diutamakan. Jika dalam suatu kelompok salah satu anggotanya tidak terjalin proses komunikasi lagi (komunikasi "ngadat") maka anggota tersebut dianggap murtad atau keluar dari NII. Selain itu, subjek menyusun rencana sebelum keluar dari NII, dimana subjek mendekati teman-temannya lagi untuk menjalin hubungan seperti dulu, setelah subjek merasakan hubungan dengan temantemannya normal kembali, subjek memutuskan resmi keluar dari NII.

Selain pengklasifikasian aspek coping menurut Lazarus, peneliti menemukan bentuk strategi coping lainnya yang tidak terdapat pada teori Lazarus, yaitu pengklasifikasian coping menurut Carver dkk. (Taylor, 2006) sebagai berikut; bentuk dari problem focused coping yaitu perilaku aktif (active coping), perencanaan (planning), penekanan terhadap aktivitas yang saling bersaing (suppression of competing), pengekangan diri (restraint coping), mencari dukungan sosial secara instrumental (seeking social of instrumental social support), sedangkan bentuk dari emotion focused coping yaitu mencari dukungan sosial secara emosional (seeking emotional social support), reinterpretasi positif (positive reinterpretation), penerimaan diri (acceptance), penyangkalan (denial), kembali kepada ajaran agama (turning to religion). Dalam penelitian ini, peneliti hanya menambahkan bentuk perilaku aktif (active coping) dan penyangkalan (denial), 
dimana kedua bentuk coping ini tidak terdapat pada teori Lazarus. Pada subjek Bunga menggunakan bentuk perilaku aktif (active coping), sementara pada subjek Bondan menggunakan bentuk penyangkalan (denial). Berdasarkan teori diatas, dapat dijelaskan bahwa pada aspek problem focused coping bentuk dari perilaku aktif (active coping) yang ditunjukkan oleh subjek Bunga, yaitu kembali pada aktivitas kuliah dan berkumpul bersama temantemannya seperti travelling setelah keluar dari NII, dalam hal ini subjek mencoba mengambil langkah-langkah yang aktif untuk memperbaiki pengaruh dampak dari NII.

Sementara itu, bentuk penyangkalan (denial) dari aspek emotion focused coping yang digunakan oleh subjek Bondan, yaitu terlihat ketika subjek dicurigai oleh teman-temannya di kampus bahwa subjek mempunyai hubungan dengan NII, kemudian subjek menyangkal pernyataan dari temannya tersebut seakan-akan subjek tidak mengetahui tentang NII, terkadang penyangkalan (denial) dapat mengatasi kecemasan yang muncul pada orang dewasa yang mengalami stres atau rasa sakit, menurut Fernandez dan Turk (Friedman dan Schustack, 2006).

Peneliti juga menemukan peniruan (modelling) seperti yang dikemukakan oleh Bandura yang dipakai dalam penggunaan strategi coping. Modelling hanya dilakukan oleh subjek Bondan, yaitu ditunjukkan ketika subjek meniru motivasi yang terdapat pada diri temannya yang juga mantan NII, yaitu dapat menata jalur hidupnya kembali normal. Dalam hal ini, dapat dijelaskan oleh Bandura (Alwisol, 2004) bahwa subjek menggunakan cara induksi live modelling untuk mencapai efikasi, dimana live modelling adalah mengamati model yang nyata yang diperoleh melalui model sosial. Efikasi akan meningkat ketika mengamati keberhasilan orang lain, sebaliknya efikasi akan menurun jika mengamati orang yang kemampuannya kirakira sama dengan dirinya ternyata gagal.

Peneliti menemukan bahwa ada fenomena menarik kalau melihat proses coping pada kedua subjek. Bentuk coping distancing digunakan terlebih dahulu oleh subjek Bondan dan Bunga sebelum menggunakan bentuk-bentuk coping yang lain dalam menghadapi masalah ketika berada di NII. Hal tersebut dikarenakan peneliti menduga kedua subjek dapat menilai suatu kondisi yang tidak nyaman lagi selama berada di NII dan tidak perlu dipertahankan untuk berada di dalamnya. Selain itu, ditemukan juga pada subjek Bondan cenderung menggunakan bentuk coping distancing, sementara pada subjek Bunga cenderung menggunakan bentuk coping planfull problem solving.

\section{Faktor-faktor yang mempengaruhi strategi coping}

Berdasarkan hasil penelitian, ada beberapa faktor yang mempengaruhi coping seperti yang diungkapkan Lazarus (Sarafino, 2008) diantaranya adalah :

\section{Kesehatan fisik}

Kesehatan fisik menjadi modal utama untuk individu dalam mengatasi setiap masalahnya. Mempunyai banyak teman juga dapat meningkatkan kesehatan fisik seseorang. Seperti yang dijelaskan oleh Cohen dkk. (Wade dan Tavris, 2007) orang yang memiliki teman dan interaksi sosial terbanyak adalah yang paling kecil kemungkinannya menjadi sakit. Hal ini sesuai dengan kondisi kedua subjek yang memiliki banyak teman dan senang bergaul, sehingga keduanya memiliki kesehatan fisik yang baik. Selain itu, menurut Roth dan Holmes (Wade dan Tavris, 2007) orang yang mengalami stres hidup rendah, mempunyai masalah kesehatan yang sedikit, sementara orang yang mengalami stres hidup tinggi, mempunyai masalah kesehatan yang tinggi. Berdasarkan teori diatas, pada subjek Bondan dan Bunga semenjak masuk hingga keluar dari NII tidak pernah sakit hingga kronis (parah), sakit yang biasa dirasakan subjek Bunga hanya batuk dan pilek. Hal ini, berkaitan dengan cara berpikir kedua subjek yang santai ketika mengalami tekanan-tekanan di NII bahkan keluar dari NII, sehingga kedua subjek memiliki kesehatan fisik yang baik. 
Seperti yang diketahui bahwa kesehatan fisik berpengaruh terhadap pengambilan coping, menurut Prawitasari (2003) orang yang disebut sehat jika mampu belajar, berpikir, bekerja, bermain, dan menyelesaikan masalah. Dari kesehatan fisik yang dimiliki oleh subjek Bondan dan Bunga, peneliti menemukan kedua subjek mampu menggunakan coping dengan baik, ditunjukkan oleh subjek Bondan yang mampu menggunakan bentuk coping distancing, escape avoidance, self control, positive reappraisal, dan denial. Diketahui bahwa subjek Bondan lebih sering menggunakan bentuk coping distancing. Sementara itu, pada subjek Bunga bentuk coping yang digunakan adalah distancing, escape avoidance, self control, accepting responsibility, positive reappraisal, planfull problem solving, dan active coping. Diketahui bentuk coping yang paling sering subjek Bunga gunakan adalah planfull problem solving.

\section{Keterampilan memecahkan masalah}

Keterampilan memecahkan masalah merupakan hal penting yang harus dimiliki oleh subjek dalam pengambilan coping. Wade dan Tavris (2007) menjelaskan jika ada orang yang dapat menghadapi masalah, menyelesaikannya, dan melaluinya, namun sesungguhnya masalahmasalah tersebut tetap penting ketika orang tersebut ingin menguasai keterampilan coping yang akan menetap dalam diri mereka. Jadi, semakin kedua subjek dihadapkan pada masalahmasalah, semakin kedua subjek memiliki keterampilan-keterampian dalam memecahkan masalah tersebut. Seperti yang diketahui, bahwa banyaknya masalah yang dihadapi oleh kedua subjek selama di NII dapat menjadikan keduanya terampil dalam memecahkan masalah. Hal ini sesuai dengan hasil penelitian, yaitu kedua subjek memiliki beberapa keterampilan untuk menyelesaikan masalahnya terutama keterampilan atau cara jitu untuk keluar dari NII, adapun keterampilan tersebut muncul dari dalam diri subjek.

Pada subjek Bondan keterampilan yang digunakan adalah mencari informasi melalui situs internet tentang NII, karena subjek merasa curiga dengan kejanggalan NII. Setelah subjek mendapatkan bukti bahwa NII merupakan aliran sesat, subjek memutuskan untuk keluar dari NII dengan cara memanfaatkan waktu liburan kampus untuk mendapatkan ijin pulang kampung agar jauh dari pengaruh NII. Sementara pada subjek Bunga keterampilan yang digunakan yaitu subjek merencanakan mendekati teman-temannya di kampus, agar ketika keluar dari NII subjek tidak merasa sendiri. Setelah subjek berhasil mendekati teman-temannya kembali, subjek keluar dari NII dengan cara memutuskan jaringan komunikasi dengan NII. Berdasarkan penjelasan tersebut, dari keterampilan yang dimiliki oleh kedua subjek, diketahui dapat membawa pengaruh terhadap keputusan pengambilan coping pada masing-masing subjek, sehingga keduanya dapat menggunakan coping dengan baik.

\section{Keterampilan sosial}

Keterampilan sosial sangat mempengaruhi dalam keberhasilan coping yang akan digunakan untuk penyelesaian sebuah masalah. Michelson (Umbara, dkk., 2012) mengemukakan keterampilan sosial sebagai keterampilan yang didapatkan individu melalu proses belajar, tentang cara melakukan hubungan sosial dengan tepat dan benar. Meliputi kemampuan berkomunikasi dan bertingkah laku yang baik terutama terhadap keluarga, teman, dan masyarakat.

Berdasarkan teori diatas, dapat dijelaskan kedua subjek memiliki keterampilan sosial yang digunakan untuk melakukan coping. Pada subjek Bunga, keterampilan yang dimiliki berupa kemampuan berkomunikasi, subjek dalam perbincangan dengan teman-temannya selalu merespon dengan jawaban yang lucu dan membuat teman-temannya tertawa. Hal ini lah yang membuat subjek banyak memiliki teman karena subjek dinilai sebagai sosok yang humoris dan pandai bergaul dengan bahan pembicaraan yang tidak monoton. Menurut Wade dan Tavris (2007) teman dapat dijadikan sumber dukungan dan kesenangan untuk mengatasi stres. 
Sementara pada subjek Bondan memiliki keterampilan berupa kemampuan berkomunikasi dan sikap sosial yang baik, ditunjukkan dari subjek mengikuti beberapa organisasi jurusan yang terdapat di kampus, "nongkrong" bersama teman-temannya, bahkan subjek mengakui sering berpindah-pindah kos untuk mendapatkan banyak teman. Adapun tujuan dari keterampilan sosial adalah untuk mendapatkan penguat, baik dari individu yang lainnya maupun dengan cara menolak hadirnya sesuatu yang tidak menyenangkan (Kelly dalam Umbara, dkk., 2012). Oleh karena itu, dengan keterampilan sosial berupa kemampuan komunikasi dan bertingkah laku baik, yang dimiliki oleh kedua subjek menjadikan keduanya dapat melakukan coping dengan baik.

\section{SIMPULAN DAN SARAN}

Berdasarkan penelitian dan pembahasan dalam penelitian ini, peneliti akan menyimpulkan mengenai strategi coping apa saja yang digunakan oleh mantan penganut aliran sesat serta faktor apa saja yang mempengaruhinya. Dalam menghadapi tekanan yang sama, diketahui kedua subjek sama-sama lebih menggunakan emotional focused coping dibandingkan menggunakan problem focused coping, dimana kedua subjek melakukan proses coping yang berbeda-beda. Melalui pendekatan emotional focused coping subjek pertama menggunakan bentuk distancing, kemudian escape avoidance, self control, positive reappraisal, dan denial. Diketahui juga subjek pertama lebih sering menggunakan bentuk coping distancing dalam mengatasi masalahnya. Selain itu, munculnya proses modeling dengan cara meniru motivasi pada diri temannya yang juga mantan aliran sesat, membuat subjek menata jalur hidupnya lebih baik lagi.

Sementara itu, bentuk coping yang digunakan oleh subjek kedua melalui pendekatan emotional focused coping, diantaranya distancing, escape avoidance, self control, accepting responsibility, dan positive reappraisal. Sedangkan dari pendekatan problem focused coping, subjek menggunakan bentuk planfull problem solving dan active coping. Diketahui juga subjek kedua lebih sering menggunakan bentuk coping planfull problem solving dalam mengatasi masalahnya.

Faktor yang mempengaruhi kedua subjek dalam melakukan coping, diantaranya faktor kesehatan fisik, keterampilan dalam memecahkan masalah, dan keterampilan sosial. Intinya, setiap individu akan berbeda-beda ketika melakukan proses coping dalam menghadapi setiap masalah yang sama, semuanya tergantung seberapa baik individu tersebut mengamati perbedaan diantara situasi yang menekan dan sumber kekuatan dalam dirinya sendiri.

Bagi individu yang sedang terlibat mengikuti aliran sesat dan ingin melepaskan diri dari aliran sesat dapat menggunakan strategi coping bentuk distancing terlebih dahulu sebelum menggunakan bentuk-bentuk coping yang lainnya. Bagi pihak-pihak yang membantu individu untuk melepaskan diri dari aliran sesat dapat melatihkan penggunaan coping bentuk distancing ini terlebih dahulu. Hal tersebut diduga dapat memudahkan dalam penggunaan bentuk-bentuk coping yang lain nantinya.

\section{DAFTAR PUSTAKA}

Almarwadi. (2012). Faktor-faktor munculnya aliran sesat. Diunduh dari http://almarwadi.wordpress.com/2012/09/29/faktor-faktor-munculnya-aliran-sesat/. 18 April 2014.

Alwisol. (2004). Psikologi kepribadian edisi revisi. Malang: UMM Press.

Fithri, H (2012). Tinjauan psikologis pada penganut aliran sesat dalam agama islam (skripsi tidak diterbitkan). Fakultas Psikologi Universitas Ahmad Dahlan, Yogyakarta. 
Folkman, S., Lazarus, R.S., Dunkel-Schetter, C., Delongis, A. \& Gruen, R.J. (1986). Dynamics of stressful encounter: cognitive appraisal coping and encounter outcomes. Journal of Personality and Social Psychology, 50, 992-1003.

Friedman, H.S. \& Schustack, M.W. (2006). Kepribadian teori klasik dan riset modern edisi ketiga. Jakarta: Erlangga.

Hadhi, M., Rizky, A., Shinta, R., \& Taufik, H. (2005). Negara Islam Indonesia: fakta sejarah dan perkembangannya. Fakultas Hukum Universitas Indonesia, Jakarta.

Indirawati, E. (2006). Hubungan antara kematangan beragama dengan kecenderungan strategi coping. Jurnal Psikologi, 3(2), 69-92.

Kuntjojo. (2009). Berpikir positif sebagai jalan menuju kehidupan yang positif. Diunduh dari http://ebekunt.wordpress.com/2009/09/25/berpikir-positif-sebagai-jalan-menuju-kekehidupan-yang-positif/. 12 juni 2014.

Lazarus, R. S. (1991). Emotion and adaptation. New York: Oxford University Press.

. (1999). Stress and emotion: a new synthesis. Springer Publishing Company.

Lestarianita, P. (2005). Perbedaan coping stres pada perawat pria dan wanita. Jurnal Psikologi, $10(2), 11-23$.

Moelong, L.J. (2012). Metodologi penelitian kualitatif. Bandung: PT. Remaja Rosdakarya.

Mulyana. (2004). Metode penelitian kualitatif: Paradigma baru ilmu komunikasi dan ilmu sosial lainnya. Bandung: PT. Remaja Rosdakarya.

Mustafa, H. (2000). Teknik sampling. Diunduh dari home.unpar.ac.id/ hasan/SAMPLING.doc. 15 Januari 2014.

Nurhayati, S.R. (2006). Peningkatan kemampuan menggunakan problem focused coping perempuan korban kekerasan dalam rumah tangga. Jurnal Humanitas, 3(1), 18-28.

Poerwandari, E.K. (2007). Pendekatan kualitatif untuk penelitian perilaku manusia. Jakarta : LPSP3. Fakultas Psikologi Universitas Indonesia.

Prawitasari. (2003). Psikologi klinis: Dari terapan mikro ke makro. Jurnal Psikologi, 18(3), 215228.

Qurays, K. (2013). Daftar aliran sesat di Indonesia. Diunduh dari http://infotercepatku.blogspot.com/2013/06/daftar-aliran-sesat-di-indonesia.html?m=1. 18 April 2014.

Perrewe, P.L. \& Ganster, D.C. (2006). Employee Health, Coping, and Methodologies. Armsterdam; Oxford: Elsevier JAI.

Rahmayati. (2010). Stres dan coping remaja yang mengalami perceraian pada orang tua. Jurnal Psikologi, 9(2), 24-38.

Safaria, T. \& Saputra, N.E. (2009). Manajemen emosi. Jakarta: PT. Bumi Aksara.

Saputra, W. (2011). Faktor-faktor yang mempengaruhi rasa bersalah mahasiswa mengakses situs porno. Fakultas Psikologi Universitas Islam Negeri Syarif, Jakarta.

Sarafino, E.P. (1998). Health psychology: Biopsychosocial Interaction. Third edition. New York: John Wiley \& Sons, Inc.

Sarafino, E.P. (2006). Health psychology: Biopsychosocial Interaction. Second edition. New York: John Wiley \& Sons, Inc.

Sarafino, E.P. \& Smith, T. W. (2008). Health psychology: Biopsychosocial Interaction. Seven edition. New York: John Wiley \& Sons, Inc.

Sarwono, J. (2006). Metodologi penelitian kuantitatif dan kualitatif. Yogyakarta: Graha Ilmu. 
UNISIA, Vol. XXXVI No. 82 Januari 2015

Sugiyono. (2011). Metodologi penelitian kuantitatif, kualitatif dan kombinasi (mixed methods). Bandung: Alfabeta, CV.

Taylor, S.E. (2006). Health psychology. New York: McGraw Hill, Inc.

Umbara, H.T.K., Lilik, S., \& Agustin, R.W. (2012). Hubungan antara kematangan emosi dan penerimaan diri dengan keterampilan sosial pada mahasiswa organisatoris. Jurnal Wacana, 8-9.

Wade, C \& Tavris, C. (2007). Psikologi edisi kesembilan. Penerjemah Mursalin dan Dinastuti. Jakarta: Erlangga.

Winarto, J. (2011). Teori belajar sosial Albert Bandura. Diunduh dari edukasi.kompasiana.com/2011/03/12/teori-belajar-sosial-albert-bandura-346947.html. 11 September 2014.

www.wikipedia.com: Republik Indonesia.17 maret 2014.

Zamihan \& Al-Ghari, M.Z. (2008). Ajaran sesat dan bahayanya terhadap agama dan negara. Institut Latihan Islam Malaysia (ILIM), Malaysia. 